УДК 336.58

Гуменюк Р.П., аспірант кафедри фінансів і банківської справи Донецького національного університету ім. Василя Стуса

\title{
АКТУАЛЬНІ ПИТАННЯ ПЛАНУВАННЯ ТА ФОРМУВАННЯ ОБОРОННОГО БЮДЖЕТУ В СУЧАСНИХ УМОВАХ
}

У статті основна увага зосереджена на узагальненні вимог чинного законодавства, інших нормативно-правових актів, власних теоретичних дослідженнях та оцінки ефективності систем оборонного та бюджетного планування в Україні. На теперішній час проводиться оборонна реформа на засадах і принципах, якими керуються держави - члени HАTO, що в свою чергу вимагає перегляду діючої системи та запровадження нових підходів та механізмів в системі оборонного та бюджетного планування.

Основним завданням є підняття проблемних питань оборонного та бюджетного планування під час формування видатків у Міністерстві оборони України, питань та неузгодженостей, які виникають під час планування виконання бюджету за видатками.

Ключові слова: оборонна реформа, оборонне та бюджетне планування, бюджет.

Літ. 13

Гуменюк Р.П.

\section{АКТУАЛЬНЫЕ ВОПРОСЫ ПЛАНИРОВАНИЯ И ФОРМИРОВАНИЯ ОБОРОННОГО БЮДЖЕТА В СОВРЕМЕННЫХ УСЛОВИЯХ}

В статье основное внимание сосредоточено на обобщении требований действующего законодательства, других нормативно-правовых актов, собственных теоретических исследованиях и оценки эффективности систем оборонного и бюджетного планирования в Украине. В настоящее время проводится военная реформа на основе и принципах, которыми руководствуются государства - члены НАТО, в свою очередь требует пересмотра действующей системы и внедрение новых подходов и механизмов в системе оборонного и бюджетного планирования. Основной задачей является поднятие проблемных вопросов оборонного и бюджетного планирования при формировании расходов в Министерстве обороны Украины, вопросов и шероховатостей, которые возникают при планировании исполнения бюджета по расходам.

Ключевые слова: законодательство, оборонная реформа, оборонное и бюджетное планирование, бюджет.

\section{Humeniuk $R$.}

\section{TOPICAL QUESTIONS OF PLANNING AND FORMATION OF DEFENSE BUDGET IN MODERN CONDITIONS}

The article focuses on generalizing the requirements of the current legislation, other normative legal acts, own theoretical studies and assessing the effectiveness of defense and budget planning systems in Ukraine. At present, defense reform is based on the principles and principles governing the NATO member states, which in turn requires a revision of the current system and the introduction of new approaches and mechanisms in the defense and budget planning system. The main task is to raise the problematic issues of defense and budget planning in the formation of expenditures in the Ministry of Defense of Ukraine, issues and roughness's that arise when planning the execution of the expenditure budget.

Key words: legislation, defense reform, defense and budget planning, budget. 
Постановка проблеми. Оборонне планування (ОП) на основі спроможностей $\epsilon$ одним із методів планування, особливістю якого $є$ розвиток спроможностей сил оборони для ефективної протидії загрозам та ризикам як військового, так i невійськового характеру 3 урахуванням імовірних сценаріїв розвитку кризових ситуацій на довгострокову перспективу, зазвичай на $10-15$ років. Даний метод оборонного планування є основним в країнах-членах НАТО.

Оборонне планування на основі спроможностей передбачає здійснення функціонального аналізу. Функції та завдання, що мають виконуватись під час очікуваних (вірогідних) майбутніх операцій, трансформуються у вимоги до спроможностей, на підставі чого планується їх створення, утримання та розвиток. Оборонне планування на основі спроможностей передбачає створення, розвиток та підтримання оптимального складу необхідних спроможностей в межах наявних ресурсів.

В той же час, показники обсягів та розподілу видатків бюджетних програм Міністерства оборони є основою для уточнення кількісно-якісних показників проекту Плану утримання та розвитку й прийняття рішення щодо проведення, перенесення або відміни його заходів.

Формування та забезпечення реалізації державної політики у сфері оборони і військового будівництва нерозривно пов'язано з вирішенням завдань ОП реформування і розвитку Збройних сил (ЗС) України.

Сьогодні фінансове забезпечення ЗС стало вирішальною ланкою всієї воєнної політики держави [12].

Аналіз останніх досліджень і публікацій. Проведений аналіз питань, присвячених питанням процесу ОП [9-13], свідчить про те, що в них узагальнено проблеми нормативно-правового та процедурного забезпечення ОП; висвітлено окремі питання розвитку процесу ОП в ЗС України; запропоновано окремі шляхи удосконалення існуючої системи та доводиться необхідність інтеграції оборонного та бюджетного планування в єдину систему.

I досі залишається багато суперечливих поглядів на загальне функціонування систем оборонного та бюджетного планування в ЗС України, але найголовнішим проблемним питанням $\epsilon$ відсутність адаптованості цих процесів один до одного в МО України, що не дозволяє здійснити інтеграцію їх в єдиний, виважений та ефективний процес подальшого розвитку ЗС України.

Оборонне планування в державі здійснюється циклічно за програмно-цільовим методом, процедурно реалізовується методом паралельності у роботі суб'єктів планування та поділяється на довго-, середньо- і короткострокове.

На сьогоднішній день в Україні під час планування та фінансування процесу розвитку ЗС України застосовуються паралельно дві системи. 3 одного боку, оборонне планування, в рамках якого відбувається планування заходів та управління програмою розвитку, а з другого - бюджетування або фінансове забезпечення ЗС України. Нині робляться спроби інтегрувати ці дві системи, але мають місце недоліки щодо узгодженості показників цих двох систем.

Стосовно вирішення питань впровадження процесу бюджетного та оборонного планування у сфері оборони відповідно до євроатлантичних принципів і підходів та узгодження бюджетного планування у сфері оборони 3 плануванням соціальноекономічного розвитку держави та національного процесу оборонного планування необхідно на законодавчому рівні удосконалити систему оборонного планування, яка буде підтримувати перехід на програмну систему оборонного та бюджетного 
планування, формування щорічного оборонного бюджету та забезпечення надійного бюджетного прогнозування на наступні два-три роки, яке буде орієнтоване на очікувані результати виконання оборонних програм.

Визначені Державною комплексною програмою реформування і розвитку ЗС України на період до 2020 року заходи уточнені та деталізовані Планами утримання та розвитку ЗС України на відповідний рік.

Удосконалення системи ОП та фінансового забезпечення і зокрема фінансового планування (бюджетного планування) набирає особливого значення в умовах проведення ООС на сході України і недостатнього фінансування потреб Національної оборони.

Одним з основних завдань оборонного планування $є$ раціональний розподіл та ефективне використання обмежених фінансових ресурсів на потреби ЗС України.

Щорічне уточнення здійснюється в ході короткострокового ОП, яке прив'язується до бюджетного процесу в Україні.

Результатами виконання процедури короткострокового планування є бюджетний запит, кошторис Міністерства оборони та Уточнений План утримання та розвитку Збройних Сил.

Необхідно звернути увагу, що на соціально-економічний розвиток України можуть суттєво вплинути ряд зовнішніх та внутрішніх ризиків і загроз. Так, ще під час розробки Прогнозу економічного і соціального розвитку України на 2018-2020 роки, схваленому постановою Кабінету Міністрів України від 01.12.2017 № 906, визначалися ризики, пов'язані із загрозою ескалації бойових дій на сході, погіршенням зовнішньоекономічної кон'юнктури на світових товарних ринках, міграційними процесами, гальмуванням інвестиційної активності, які зберігаються і на теперішній час. У поточному році вплив на економіку продовжують здійснювати припинення переміщення вантажів через лінію розмежування 3 тимчасово окупованими територіями, а також обмеження на транзит українських товарів через територію Російської Федерації.

Така ситуація, а також необхідність зменшення дефіциту державного бюджету разом з необхідністю забезпечення соціальних виплат, виконання боргових зобов'язань та передбачення належного обсягу видатків для забезпечення обороноздатності держави вимагає від головних розпорядників бюджетних коштів забезпечення ефективного використання бюджетних коштів та виконання пріоритетних завдань, визначених стратегічними документами держави в межах визначених їм видатків на 2019-2020 роки.

Виклад основного матеріалу. Бюджетний кодекс України визначає чітку модель розробки, складання й затвердження Державного бюджету, а Закон України «Про організацію оборонного планування» - засади реалізації державної політики щодо належного фінансового забезпечення потреб національної безпеки та оборони. Розподіл обмежених ресурсів, без сумніву, $\epsilon$ одним 3 найважчих рішень i найскладніших функцій як виконавчої, так і законодавчої гілок влади.

Це означає, що існує проблема розподілу цих ресурсів - головним чином фінансів та опосередковано - людських і матеріальних ресурсів та інфраструктури, 3 метою виконання пріоритетів та задоволення основних потреб.

Відповідно до статті 21 Бюджетного кодексу України, Міністерство фінансів України за участю головних розпорядників коштів оборонного бюджету складає прогноз бюджету військових фінансів на планові бюджетні періоди. 
Механізм формування оборонного бюджету потребує особливої уваги й максимально можливої деталізації. Спочатку, відповідно до поставлених завдань, у військових частинах, закладах та установах визначають потребу в матеріальних і фінансових ресурсах для виконання завдань кожним із цих підрозділів у наступному році. У процесі розрахунків визначають нормативну потребу за всіма видами забезпечення. Конкретні нормативи необхідного фінансового та матеріального забезпечення, як правило, встановлюється відомчими документами, а саме наказами міністра оборони України та начальника Генерального штабу ЗСУ.

Однак, попри значні досягнення у формуванні багатьох важливих складових військових фінансів, наявна система бюджетного прогнозування та планування характеризується комплексом фундаментальних проблем, основними 3 яких $\epsilon$, поперше, відірваність бюджетного прогнозування від загальнодержавного планування. Водночас відсутній чіткий зв'язок між державним та оборонним бюджетним плануванням, що призводить до того, що формування бюджету військових фінансів здійснюється не за принципом реальних потреб, а за залишковим принципом, тобто безвідносно до пріоритетів Державної комплексної програми реформування та розвитку $3 \mathrm{CУ}$.

По-друге, має місце прецедент, коли бюджетне прогнозування фактично підпорядковується короткостроковому бюджетному плануванню, а не навпаки. Фактично як бюджетне прогнозування, так i фінансове планування мають декларативний характер, оскільки плановий прогноз не є реальним орієнтиром і не збігається $з$ реаліями бюджетного фінансування. По-третє, досить часто програмноцільовий метод формування й розподілу військових фінансів базується не на стратегічних завданнях, а супроводжується не завжди вірно обраною системою показників.

За таких умов порушується глибинна сутність сучасної оборонної стратегії, iї здатність визначати широкий спектр назрілих завдань і цілей. Зрозуміло, що подібні планові деформації мають своїм наслідком порушення фінансової політики, тобто реально ускладнюють виконання завдань щодо досягнення необхідної обороноздатності країни найбільш фінансово-раціональним шляхом.

Оборонна структура має бути і результативною, і ефективною одночасно, тобто здатною досягати бажаного результату. Водночас, здатною досягати потрібного результату, мінімізуючи витрати коштів. На сьогодні основним викликом для сучасної оборонної структури є забезпечення нового балансу між завданнями збройних сил і наявними фінансовими ресурсами.

Оборонний бюджет має визначатися з урахуванням рівня безпеки й загроз, які стоять перед державою. Але насправді обмеженість державних ресурсів призводить до того, що витрати на оборону визначаються, виходячи 3 наявних ресурсів та рівня інфляції, а не з реального рівня загроз безпеці держави.

Кожного року під час прийняття бюджету на наступний рік перед політиками постає завдання адекватного розподілу ресурсів, наявних у державі. Ті самі обмеження стосуються й розподілу оборонного бюджету, тобто обмежені ресурси необхідно розподілити таким чином, щоб це давало можливість виконати поставлені завдання у сфері оборони держави. Однак потреби оборони традиційно забезпечувалися за залишковим принципом.

Сам бюджетний процес $є$ прозорим і дозволяє на всіх рівнях керівництву Збройних Сил реально оцінювати обсяги потреб у фінансових ресурсах, як то на рівні 
командира частини, так і на рівні Головнокомандувача Збройних Сил та Міністра оборони і приймати безпосередню участь у цьому процесі.

На сьогоднішній день оборонне планування має за мету забезпечити можливості Збройних Сил України щодо виконання поставлених завдань, а бюджетне планування в оборонній сфері забезпечує державні правила (Бюджетний кодекс) з планування та виконання бюджету МО України.

Сьогодні головним принципом програмно-цільового методу планування $\epsilon$ орієнтація програми на кінцеву ціль - зміцнення обороноздатності держави.

Головна мета вирішення існуючих проблемних питань інтегрування процесів оборонного та бюджетного планування в МО України полягає в ліквідації розриву в системі планування розвитку та життєдіяльності Збройних Сил України, який існує сьогодні. Інтеграція процесів оборонного та бюджетного планування необхідна для подальшого створення таких Збройних Сил, які були б здатні виконувати поставлені перед ними завдання за обсягами ресурсів, які реально на них плануються та виділяються.

Не варто забувати й про те, що Стратегічним оборонним бюлетенем визначені завдання щодо розвитку системи ОП як складової національної системи планування у секторі безпеки і оборони.

Мають бути впроваджені сучасні методи, що використовуються країнамичленами НАТО для посилення власних оборонних спроможностей, зокрема, метод планування на основі спроможностей (Capability Based Planning).

Це дасть змогу удосконалити процедури ОП, узгодити їх з бюджетним процесом та забезпечить програмне управління оборонними ресурсами.

Процес ОП, що запроваджений в Україні, має низку проблемних питань, які заважають його ефективному функціонуванню, про що свідчить кризовий стан об'єкту планування - ЗС України. Це констатується п. 3.3 Стратегії національної безпеки України, затвердженої у червні 2012 року: "На тлі зростання викликів і посилення загроз національній безпеці зберігається невідповідність сектору безпеки і оборони України завданням захисту національних інтересів, що характеризується ... триваючим погіршенням стану Збройних Сил України і оборонної промисловості...” [8].

Отже, невідповідність окремих елементів оборонного та бюджетного планування - $є$ важливим чинником, який впливає на процес короткострокового ОП.

3 метою вдосконалення механізму короткострокового ОП існує нагальна потреба у запровадженні системи постійного моніторингу (вимірювання результативності та ефективності) виконання як оборонних (напрямів (завдань), так і бюджетних програм. Запровадження механізму зворотного зв'язку щодо ефективності використання не тільки бюджетних коштів, але й виконання заходів оборонних програм, дозволить оперативно приймати відповідні управлінські рішення.

На сьогодні започатковано періодичне (квартальне) звітування за виконання бюджетних програм (підпрограм). 3 такого аналізу можливо зробити висновок про рух коштів, динаміку та структуру видатків у МО України. Разом 3 тим, відсутність звітування за результативними показниками напрямів (завдань) відповідно до ПУР ЗСУ не дозволяе оперативно відслідковувати стан виконання заходів та ефективність використання ресурсів для досягнення кінцевої мети зазначених програм [13].

В умовах ринкових перетворень, які відбуваються в Україні формування оборонного бюджету є досить складним процесом, який відбувається в загальному бюджетному процесі держави, але має свої особливості пов'язані із специфікою завдань, які покладені на Збройні Сили України. 
3 метою встановлення загальнодержавних узгоджених процедур, методів i механізмів визначення обрису Збройних Сил та інших військових формувань, необхідних для реалізації політики держави у сфері безпеки i оборони, а також координації відповідних планів у цій сфері на національному та міждержавному рівнях в Україні впроваджується адаптована до вимог НАТО система ОП.

Процес ОП враховує низку чинників, до найбільш важливих 3 яких слід віднести: оцінку воєнно-політичної та воєнно-стратегічної ситуації; кількісні та якісні показники угруповань військ (сил), необхідних для виконання визначених завдань у сфері безпеки і оборони; раціональний розподіл відповідальності між оборонними складовими держави; розвиток воєнних технологій; фінансові спроможності держави тощо. Таким чином забезпечується прийняття рішень на політичному та суто військовому рівнях 3 метою найбільш оптимального використання національних оборонних ресурсів.

Відповідно до Державної комплексної програми реформування і розвитку Збройних Сил вже з 2018 року МО України перейшло до оборонного планування на основі спроможностей, але у нас є також необхідність враховувати загрози, про що сказано в Стратегії національної безпеки.

Система ОП на основі існуючих загроз була притаманна колишньому Радянському Союзу і країнам-членам НАТО в роки холодної війни. Наступним етапом розвитку системи ОП $\epsilon$ планування на основі спроможностей, які дозволяють виконувати завдання та відповідати на ширший спектр загроз в їх динаміці. Спроможності - це бойові бригади, це озброєння, літаки і кораблі, системи автоматизації та інші складові, з яких складаються Збройні Сили і до яких висуваються відповіді вимоги. Досягнення визначених спроможностей дозволяє враховувати всі можливі сценарії розвитку обстановки і визначати завдання із оборони держави, захисту ії суверенітету та територіальної цілісності.

Стратегічна мета щодо досягнення спроможностей стосується впровадження більш ефективної підготовки військ/сил, інтеграції у цей процес стандартів НАTO i, що дуже важливо, врахування досвіду, який ми набули під час виконання завдань в ході антитерористичної операції. Виконання заходів оборонного планування в Україні має забезпечувати:

спроможність держави протистояти загрозам національній безпеці України у воєнній сфері в сучасних умовах та адекватно реагувати на їх розвиток;

здатність України бути складовою частиною системи міжнародної безпеки;

готовність держави до міжнародної взаємодії та врегулювання міжнародних i внутрішніх криз через застосування відповідних механізмів;

розвиток Збройних Сил, які мають перебувати у встановленому стані готовності до виконання завдань за призначенням;

участь у заходах з міжнародного співробітництва (на дво- і багатосторонніх засадах) та в міжнародних миротворчих операціях;

підтримання необхідних бойових можливостей Збройних Сил для проведення операцій (бойових дій).

ОП в ЗС України здійснюється в загальній системі планування розвитку Воєнної організації України та передбачає:

вироблення й забезпечення реалізації стратегії розвитку Збройних Сил i створення єдиної бази даних для його планування;

оперативно-стратегічне обгрунтування структури Збройних Сил; 
наукове, юридичне та фінансово-економічне обгрунтування програмних заходів щодо їх утримання, реформування й розвитку;

безпосереднє формування, координацію, затвердження програм i планів розвитку Збройних Сил на довго-, середньо- та короткострокову перспективи.

Система ОП в Україні - це інтегруюча складова систем планування оборони держави, управління державними ресурсами у сфері оборони та бюджетного планування. Принципово система ОП України наближена до відповідних процедур, прийнятих у НАТО і СС, що в перспективі максимально спрощує процес ії адаптації до вимог колективного планування. Однією з наріжних складових національної системи ОП є Процес планування та оцінки сил НАТО, який поряд із рекомендаціями Спільної робочої групи Україна-НАТО з питань воєнної реформи використовується Україною для реалізації завдань реформування та розвитку Збройних Сил.

Суб’єктами ОП в Збройних Силах є структурні підрозділи Міністерства оборони та Генерального штабу ЗС України за напрямами їх відповідальності. Об'єктами ОП є види ЗС України та об'єднання, з'єднання, військові частини, військові навчальні заклади, установи й організації, що не належать до видів ЗС України.

Отже, всебічно скоординований процес ОП має забезпечити формування Збройних Сил 3 необхідним рівнем їх готовності до виконання завдань як на національному рівні, так і в рамках операцій, спільних 3 НАТО і Європейським Союзом.

Не менш важливим є розв’язання питань фінансового забезпечення ЗС України, a саме:

- досягнення максимальної ефективності використання коштів, передбачених на потреби оборони; передбачення можливості поступової заміни техніки модернізованою та новою, а також підтримання високого коефіцієнта іiї технічної готовності;

- забезпечення постійного зростання обсягів фінансування бойової підготовки Збройних Сил та іiі матеріально-технічного забезпечення 3 метою зведення інтенсивності та якості польового, повітряного й морського вишколу на рівень, що існуе в арміях розвинених країн.

Водночас зменшення 3 тих чи інших причин обсягів фінансування негативно вплине на терміни та якість виконання планів створення армії нового типу.

Таким чином, одним із вкрай важливих завдань держави має бути фінансове забезпечення Збройних Сил у межах прогнозованих видатків на потреби оборони. Воно має перебувати під контролем Верховної Ради України, Кабінету Міністрів України тощо

Висновки. В оборонному плануванні розвиток Збройних Сил не відокремлюється від планування їх застосування. Під час реалізації оборонного планування (довго-, середньо- або короткострокового) розвиток Збройних Сил планується стосовно виконання відповідних завдань. Тобто спочатку оцінюється рівень воєнних загроз і характер сучасних воєнних конфліктів і тенденцій розвитку збройної боротьби, визначається перелік ситуацій застосування Збройних Сил, формуються їх завдання і моделюється порядок виконання, визначаються необхідні сили й засоби, а потім плануються заходи, які потрібно провести для досягнення намічених цілей. На даному етапі заходи оборонного планування та стратегічного застосування Збройних Сил плануються паралельно і майже незалежно одне від одного.

Ефективне та результативне використання бюджетних коштів $є$ одним 3 найважливіших завдань планування i виконання бюджету в умовах обмежених 
ресурсів. Важливим є удосконалення системи управління видатками бюджету в частині підвищення результативності їх використання.

Подальший розвиток системи планування бюджету, що грунтується на принципах програмно-цільового методу, потребує удосконалення стадій бюджетного процесу щодо підсилення дієвості середньострокового планування бюджету та підвищення ефективності використання бюджетних коштів.

3 метою адаптації системи управління ЗС України до євроатлантичної моделі органів військового управління та їх взаємної функціональної сумісності Збройні Сили України приступили до переходу на Ј-структури. Реалії сьогодення свідчать, що в контексті трансформаційних процесів на євроатлантичному просторі практично весь західний кордон України межує з країнами НАТО. Цей чинник, а також загальні процеси глобалізації на європейському континенті спричинили докорінний перегляд системи національної безпеки України, яка логічно трансформувалася в державне рішення щодо євроатлантичної інтеграції.

\section{Література:}

1. Конституція України. - К.: Основи, 1996.

2. Закон України "Про Збройні Сили України" // Законодавство України 3 питань військової сфери. - С. 72-78.

3. Закон України "Про оборону України" від 06.12.91 № 1932-XII.

4. Закон України "Про організацію оборонного планування" від 18.11.2004 № 2198-IV.

5. Закон України "Про державні цільові програми" від 18.03.2004 № 1621-IV.

7. Указ Президента України від 24.09.15 № 555/2015 Про рішення Ради національної безпеки і оборони України від 2 вересня 2015 року "Про нову редакцію Воєнної доктрини України".

8. Стратегічний оборонний бюлетень України. - К.: МО України, 2013. -60 с. Указ Президента України від 29 грудня 2012 року № 771/2012.

9. Про нову редакцію Стратегії національної безпеки України. - К.: РНБО України, 2013. -19с. Указ Президента України від 8 червня 2012 року № 389/2012.

10. Постанова Кабінету Міністрів України від 05.04.2006 № 447 "Про затвердження Порядку організації та фінансування стратегічного планування у сфері оборони і військового будівництва".

11. Наказ Міністра оборони України від 17.11.2016 року № 610 „Про затвердження Положення про середньострокове та короткострокове планування в Міністерстві оборони України і Збройних Силах України ”.

12. Наказ Міністерства оборони України та Генерального штабу Збройних Сил України від 19.12.17 № 670 "Про організацію оборонного планування в Міністерстві оборони України і Збройних Силах України у 2018 році на 2019-2021 роки”.

13. Проблемні питання інтегрування оборонного й бюджетного планування в єдину систему. Збірник наукових праць ХУПС, 2011 рік, випуск 3 (29).

14. Аналіз чинників, які впливають на процес короткострокового оборонного планування. Наука і техніка Повітряних Сил Збройних Сил України, 2013, № 3(12). 